\title{
Yield of eggplant using low quality water and pulse drip irrigation
}

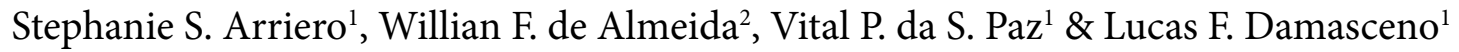 \\ ${ }^{1}$ Universidade Federal do Recôncavo da Bahia/Programa de Pós-Graduação em Engenharia Agrícola/Núcleo de Engenharia de Água e Solo. Cruz das \\ Almas, BA, Brasil. E-mail: stephaniearriero@hotmail.com - ORCID: 0000-0002-6857-1673; vitalpaz@ufrb.edu.br (Corresponding author) - ORCID: \\ 0000-0002-8034-668X; lucas_farias13@hotmail.com - ORCID: 0000-0002-2755-0278 \\ ${ }^{2}$ Instituto Federal do Espírito Santo. Barra de São Francisco, ES, Brasil. E-mail: willian.almeida@ifes.edu.br - ORCID: 0000-0001-7394-2865
}

\begin{abstract}
The use of saline water and wastewater in agriculture has been increasingly considered, and this is due to the increase in awareness about the conservation of natural resources and population growth, implying a greater demand for food. Drip irrigation already has many benefits and, with the splitting of the depths to be applied, results in pulse drip irrigation, which further favors the plant by providing more constant moisture in the soil. The objective of this study was to evaluate the effects of the application of wastewater and saline water by pulse drip irrigation on eggplant yield and water use efficiency. The experimental design was randomized blocks in $2 \times 5$ factorial scheme, corresponding to continuous and pulse drip irrigation and five types of water (municipal, saline (sodium chloride), saline (calcium chloride), wastewater, and a mix of saline (sodium chloride) and wastewater), with five repetitions. Water use efficiency was quantified according to the water applied and the production. Pulse drip irrigation promoted higher marketable fruit yield. The best performance of eggplant was verified when wastewater was applied via pulse drip irrigation. Wastewater via pulse drip irrigation can be used to grow eggplant for higher marketable yield and water use efficiency.
\end{abstract}

Key words: Solanum melongena L., irrigation, wastewater

\section{Rendimento da berinjela com uso de água de baixa qualidade e gotejamento por pulsos}

RESUMO: O uso de água salobra e residuária na agricultura vem sendo cada vez mais considerado e isto se deve ao aumento da conscientização sobre a conservação dos recursos naturais e do crescimento populacional implicando na maior demanda de alimentos. A irrigação por gotejamento apresenta inúmeros benefícios, com o parcelamento da lâmina a ser aplicada resulta no gotejamento por pulsos, favorecendo ainda mais a planta por conferir ao solo umidade mais constante. O objetivo neste estudo foi avaliar os efeitos da aplicação de água residuária e salobra via gotejamento por pulsos na produção da berinjela e a eficiência do uso da água. $\mathrm{O}$ delineamento experimental foi blocos casualizados em esquema fatorial $2 \times 5$, referente a gotejamento contínuo e por pulsos e cinco tipos de água (abastecimento municipal, salobra (cloreto de sódio), salobra (cloreto de cálcio), residuária e mistura de água salobra (cloreto de sódio) com água residuária) em cinco repetições. A eficiência do uso da água foi estimada considerando a água aplicada e a produção obtida. A aplicação por pulsos proporcionou maior quantidade de frutos comerciais. O melhor desempenho da berinjela foi verificado ao aplicar água residuária via gotejamento por pulsos. Água residuária via irrigação por pulsos pode ser utilizada no cultivo de berinjela para uma maior produção comercial e eficiência do uso da água.

Palavras-chave: Solanum melongena L., irrigação, água residuária 


\section{INTRODUCTION}

The reuse of water should be considered as the efficient use of water, which also includes the control of losses and waste and the minimization of effluent production (Cunha et al., 2011). Water is one of the resources with major limitation in the semiarid region and, to mitigate this problem, the use of saline water and wastewater in the irrigation of agricultural crops is considered (Medeiros et al., 2017; 2018). Medeiros et al. (2015) state that irrigation with wastewater emerges as a source of water and nutritional resources for eggplant crop.

Moura \& Carvalho (2014) state that soil salinity management should be performed considering, in addition to irrigation water, the use of tolerant cultivars, climate, type of soil and management practices, as these factors can influence soil salinity and crop yield. According to Ünlünkara et al. (2010), eggplant is a crop considered moderately sensitive to salinity.

Correct use of wastewater for irrigation saves surface water and benefits the soil, because organic matter and nutrients are being deposited, so the environment is being preserved (Costa et al., 2012). According to Medeiros et al. (2017), under semiarid conditions, it is possible to produce eggplant using wastewater, minimizing the application of mineral fertilizers. Santos et al. (2018), studying salt stress in eggplant, observed that the variables yield, length, fresh mass and number of fruits per plant decreased with the increase in irrigation water salinity.

In current agriculture, the search for techniques that improve crop yields and water use efficiency is crucial. Pulse drip irrigation stands out within this perspective, as it generates positive results in terms of yield, quality of products, water savings, maintenance of soil moisture, among others (Eid et al., 2013). There are still few studies about the effects of pulse drip irrigation using wastewater and saline water on crop yield.

The present study aimed to evaluate the production variables and water use efficiency of eggplant, using saline water $\left(\mathrm{NaCl}\right.$ and $\left.\mathrm{CaCl}_{2}\right)$ and wastewater, comparing pulse irrigation with continuous irrigation.

\section{Material ANd Methods}

The study was conducted in a protected environment, in the experimental area of the Graduate Program in Agricultural Engineering of the Universidade Federal do Recôncavo da Bahia (UFRB), located in the municipality of Cruz das Almas, BA, Brazil, at $12^{\circ} 40^{\prime} 19^{\prime}$ S, $39^{\circ} 6^{\prime} 23^{\prime \prime} \mathrm{W}$, and altitude of $220 \mathrm{~m}$, located in the Recôncavo Baiano region.

The soil used was classified as Oxisol of low fertility, with the following chemical characteristics: $\mathrm{OM}=1.12 \% ; \mathrm{pH}=4.30$; $\mathrm{P}=10.00 \mathrm{mg} \mathrm{dm}^{-3} ; \mathrm{K}=40.00 \mathrm{mg} \mathrm{dm}^{-3} ; \mathrm{Ca}=1.00 \mathrm{cmol}_{\mathrm{c}} \mathrm{dm}^{-3}$; $\mathrm{Mg}=0.60 \mathrm{cmol}_{\mathrm{c}} \mathrm{dm}^{-3} ; \mathrm{H}+\mathrm{Al}=3.00 \mathrm{cmol}_{\mathrm{c}} \mathrm{dm}^{-3} ; \mathrm{Al}=$ $0.70 \mathrm{cmol} \mathrm{dm}_{c}^{-3} ; \mathrm{CEC}=4.74 \mathrm{cmol} \mathrm{dm}_{\mathrm{c}}^{-3} ; \mathrm{V}=36.70 \%$.

The soil was placed in containers with capacity of $100 \mathrm{~L}$ spaced at $1 \times 1.5 \mathrm{~m}$.

The wastewater used came from the Treatment Station of the Empresa Baiana de Águas e Saneamento (EMBASA) located in Muritiba, BA, Brazil. Its physico-chemical characteristics were: $\mathrm{pH}=7.80 ; \mathrm{EC}=1.00 \mathrm{dS} \mathrm{m}{ }^{-1} ; \mathrm{P}=0.05 \mathrm{mg} \mathrm{L}^{-1} ; \mathrm{K}=$
$29.32 \mathrm{mg} \mathrm{L}^{-1} ; \mathrm{N}=21.85 \mathrm{mg} \mathrm{L}^{-1} ; \mathrm{Na}=138.00 \mathrm{mg} \mathrm{L}^{-1} ; \mathrm{Ca}=15.00$ $\mathrm{mg} \mathrm{L}^{-1} ; \mathrm{Mg}=18.96 \mathrm{mg} \mathrm{L}^{-1} ; \mathrm{Cl}=175.83 \mathrm{mg} \mathrm{L}^{-1} ; \mathrm{SO}_{4}^{2-}=$ absent; $\mathrm{CO}_{3}=$ present $\mathrm{HCO}_{3}{ }^{-}=238.51 \mathrm{mg} \mathrm{L}^{-1} ; \mathrm{SAR}=5.55\left(\mathrm{mmol} \mathrm{L}^{-1}\right)^{0,5}$.

The saline waters, with EC equal to $2.5 \mathrm{dS} \mathrm{m}^{-1}$, were obtained by adding sodium chloride $(\mathrm{NaCl})$ and calcium chloride $\left(\mathrm{CaCl}_{2}\right)$ salts to the water, according to the treatment, adjusting the EC value using a benchtop conductivity meter with temperature correction. The supply water used to prepare the solution had EC from 0.3 to $0.5 \mathrm{dS} \mathrm{m}^{-1}$. In the mixture used for one of the types of water, which consisted of the mixture of saline water and wastewater, half was water with $\mathrm{NaCl}$ and the

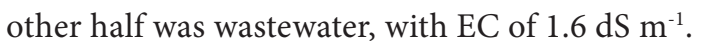

The experimental design used was randomized blocks, in a factorial scheme, with 10 treatments $(2 \times 5)$, corresponding to two forms of water application: continuous drip (CD) and pulse drip (PD) and five types of water: supply water (W1), saline water $(\mathrm{NaCl})(\mathrm{W} 2)$, saline water $\left(\mathrm{CaCl}_{2}\right)(\mathrm{W} 3)$, wastewater (W4) and mixture of saline water with wastewater, in the proportion of $1 / 1$ (W5), with 5 repetitions, totaling 50 experimental units.

Sowing was performed in polyethylene trays with 50 cells, containing commercial substrate mixed with coconut fiber in the proportion of 1:2 (v/v), and three seeds were placed per cell. At 15 days after sowing (DAS), thinning was carried out leaving only one plant per cell.

Liming and fertilization were performed based on soil chemical analysis. Top-dressing fertilization was also performed, being split into three portions, following the recommendations for the crop proposed by Trani (2014).

Irrigation was applied with a drip system, using conventional emitters, with operating flow rate of $2.1 \mathrm{~L} \mathrm{~h}^{-1}$ and application uniformity of $91 \%$. The emitters were connected to $5-\mathrm{mm}$ diameter microtubes in 20-mm-diameter polyethylene tubes, one dripper per pot.

The pulse drip irrigation consisted of the splitting of the irrigation depth into six irrigation pulses with intervals of 30 $\mathrm{min}$ (irrigation/rest). The pulses started at 9:00 a.m. and lasted enough to apply $1 / 6$ of the required water depth.

Pulse irrigation was controlled using a digital controller, with four outputs and 24 programs, divided into six for each output. The applied water depth was calculated using the characteristic soil-water retention curve, according to the model of Genuchten (1980) presented in Eq. 1.

$$
\theta=0.101+\left\{\frac{0.4860 .101}{\left[1+(0.056|\Psi|)^{1.345}\right]^{0.256}}\right\}
$$

where:

$\theta \quad$ - soil moisture $\left(\mathrm{cm}^{3} \mathrm{~cm}^{-3}\right)$; and,

$\Psi \mathrm{m}$ - matric potential $(\mathrm{kPa})$.

The model was fitted using the program Soil Water Retention Curve - SWRC (Dourado Neto et al., 2000).

In at least three replicates of each treatment, one tensiometer was installed per box. After 30 DAS, transplanting was performed and daily irrigations began to be applied, using 
an initial depth of $3 \mathrm{~mm}$ for 10 days. This procedure was adopted in order to promote the establishment and acclimation of the seedlings. Subsequently, irrigations were performed according to the reading of the tensiometers installed at $0.15 \mathrm{~m}$ depth and based on the information obtained from the soil-water retention curve.

Irrigation was performed when the average water tension in the soil reached $-15 \mathrm{kPa}$, reducing it to $-10 \mathrm{kPa}$ (field capacity). The operation time of the irrigation system was calculated from the determined gross depth, considering the effective depth of the root system equal to $0.30 \mathrm{~m}$.

Eggplant yield was evaluated in weekly harvests throughout the experiment, according to fruit length $(>14 \mathrm{~cm})$. Together with the harvest of marketable fruits, the fruits that suffered some kind of injury and/or malformation were also harvested. The number of marketable fruits (NMF), number of total fruits (NTF), total yield $\left(\right.$ g plant $^{-1}$ ) (TY) and marketable yield (MY) were then analyzed.

Water use efficiency of (WUE, $\mathrm{kg} \mathrm{m}^{-3}$ ), considering the total yield (WUETOT) and marketable yield (WUEMAR), was obtained in kg of fruits (total or marketable) produced per plant per $\mathrm{m}^{3}$ of water applied by irrigation (Eq. 2):

$$
\mathrm{WUE}=\frac{\mathrm{P}}{\mathrm{L}}
$$

where:

$\mathrm{P}$ - crop production, in $\mathrm{kg} \mathrm{plant}^{-1}$; and,

L - water applied, in $\mathrm{m}^{3}$.

The data were subjected to analysis of variance. When significant by the F test, the mean data were compared by Tukey test ( $\mathrm{p} \leq 0.5)$. Statistical analyses were carried out using the statistical program SISVAR version 4.6 (Ferreira, 2014).

\section{Results AND Discussion}

For the NTF variable, the unfolding of the interaction (Table1) shows that there was no significant difference between the continuous drip (CD) and pulse drip (PD) with the waters $\mathrm{W} 1, \mathrm{~W} 2$ and $\mathrm{W} 4$. For waters $\mathrm{W} 3$ and $\mathrm{W} 5$, application via $\mathrm{CD}$ resulted in higher means compared to $\mathrm{PD}$.

For NMF, a comparison of CD with PD showed a positive effect of the application of W2 and W4, resulting in increments of 109 and $66.7 \%$ when PD was used. Opposite response was observed for $\mathrm{W} 3$, as its application via $\mathrm{PD}$ resulted in a 50\% reduction in NMF. For waters W 1 and W5, there were no significant differences between the forms of irrigation (Table 1).

Losses due to injury or malformation of fruits were more significant for irrigation via CD, as these ranged between $19.4 \%$ (W1) and 47.62\% (W2) regarding the difference between NTF and NMF (Table 1). While no loss was observed with irrigation via PD using W4, the application of W5 resulted in a $20 \%$ reduction. These results point to the presence of salinity in the waters that most affected NMF, especially W2 (via CD) and W5 (via PD). More attention should be paid to the latter, since the difference between it and W4 is the addition of saline water $(\mathrm{NaCl})$, and $\mathrm{W} 4$ did not lead to reduction (via $\mathrm{PD})$, which makes it possible to associate the losses with the salinity.

The probable explanation for this result is related to the effects of salinity, as the retention forces by osmotic effect increase, which does not favor the absorption of water and nutrients by plants, causing a negative effect on their development (Dias et al., 2016).

The absence of losses when irrigating with $\mathrm{W} 4$ via $\mathrm{PD}$ (Table 1) may be due to the fact that wastewater is a major supplier of nutrients to the plant, which are favorable to its growth, development and production, according to a study conducted by Medeiros et al. (2017). This factor is further intensified by the type of drip irrigation in question because, according to Almeida (2016), this technique promotes a more elongated horizontal bulb in the soil, leaving the moisture more concentrated close to the surface, so it is maintained for longer time due to the splitting of the water depth.

When analyzing the AFW, it is possible to verify that there was no difference between the different types of water applied via $C D$. For $P D$, the highest values of AFW were associated with the use of W3 (360.59 g) and W5 (348.48 g), which differed from the other types of water. The types of drip irrigation differed from each other only when using W3 and W5, where PD was superior to CD (Table 1).

When using W3 and W5 applied via PD, opposite results can be observed, with the lowest means for NMF and highest means for AFW. This may indicate that PD favored the transport of photosynthetic assimilates to the few existing fruits, making them of good commercial quality (Table 1).

A result close to those found in the present study was observed by Antonini et al. (2002), who studied different eggplant hybrids and obtained for cv. Florida Market average production of seven marketable fruits per plant, with length between 13 and $17 \mathrm{~cm}$ and average weight of $299.5 \mathrm{~g}$. For fruits

Table 1. Number of total fruits (NTF), number of marketable fruits (NMF) and average fruit weight (AFW) as a function of type of water and drip irrigation system

\begin{tabular}{|c|c|c|c|c|c|c|}
\hline \multirow{3}{*}{ Type of water } & \multicolumn{6}{|c|}{ Means } \\
\hline & \multicolumn{2}{|c|}{ NTF } & \multicolumn{2}{|c|}{ NMF } & \multicolumn{2}{|c|}{ AFW (g) } \\
\hline & PD & CD & PD & CD & PD & CD \\
\hline W1 & $5.40 \mathrm{aA}$ & $6.20 \mathrm{aA}$ & $5.00 \mathrm{aAB}$ & $5.00 \mathrm{aA}$ & $233.92 \mathrm{aB}$ & $256.57 \mathrm{aA}$ \\
\hline W2 & $5.00 \mathrm{aA}$ & $4.20 \mathrm{aA}$ & $4.60 \mathrm{aAB}$ & $2.20 \mathrm{bB}$ & $282.34 \mathrm{aB}$ & $246.54 \mathrm{aA}$ \\
\hline W3 & $2.20 \mathrm{bB}$ & $5.80 \mathrm{aA}$ & 2.00 bC & $4.00 \mathrm{aAB}$ & $360.59 \mathrm{aA}$ & $232.81 \mathrm{bA}$ \\
\hline W4 & $6.00 \mathrm{aA}$ & $6.20 \mathrm{aA}$ & $6.00 \mathrm{aA}$ & $3.60 \mathrm{bAB}$ & $258.01 \mathrm{aB}$ & $269.90 \mathrm{aA}$ \\
\hline W5 & $4.00 \mathrm{bAB}$ & $5.80 \mathrm{aA}$ & $3.20 \mathrm{aBC}$ & $4.40 \mathrm{aA}$ & $348.48 \mathrm{aA}$ & $244.50 \mathrm{bA}$ \\
\hline CV (\%) & \multicolumn{2}{|c|}{25.05} & \multicolumn{2}{|c|}{27.07} & \multicolumn{2}{|c|}{11.99} \\
\hline
\end{tabular}

Means followed by the same lowercase letter in the row and uppercase letter in the column do not differ by Tukey test at p $\leq 0.05$; CD - Continuous drip; PD - Pulse drip; W1 - Supply water; W2 - Saline water $(\mathrm{NaCl})$; W3 - Saline water $\left(\mathrm{CaCl}_{2}\right)$; W4 - Wastewater; W5 - Mixture of saline water $(\mathrm{NaCl})$ and wastewater 
longer than $17 \mathrm{~cm}$, these authors observed AFW of $362.5 \mathrm{~g}$, which is very close to that observed with the application of W3 and W5 via PD.

For total yield (TY), the application of $\mathrm{W} 3$ via $\mathrm{PD}$ resulted in the lowest mean (765.45 g plant $\left.^{-1}\right)$, not differing statistically from W1 (1253.71 $\mathrm{g} \mathrm{plant}^{-1}$ ), which did not differ from the other types of water (Table 2). On the other hand, in CD the highest mean of TY was observed (1587.62 g plant $^{-1}$ ) with the application of $\mathrm{W} 1$, but there was no statistical difference between the types of water. Among the types of drip irrigation, there was a difference only using the water W3, with lower value in irrigation via PD (Table 2).

The highest mean MY (1559.22 g plant $\left.^{-1}\right)$ was obtained when applying W4 via PD, differing statistically only from W3 (721.19 g plant $\left.^{-1}\right)$, which did not differ from W1 and W5. When applying W2 via CD, the lowest mean MY was verified, and this was $544.43 \mathrm{~g} \mathrm{plant}^{-1 ;}$ this type of water differed only from W1, which did not differ from the other ones (Table 2).

$\mathrm{CD}$ was inferior to $\mathrm{PD}$ for the MY variable when applying $\mathrm{W} 2$ and W4 (Table 2). As observed in the variables related to the number of fruits, the reduction in production was also significant between TY and MY, especially via CD. When W2 was applied via CD, the reduction in MY yield was $49.2 \%$. For $\mathrm{PD}$, the largest reduction in MY was $24 \%$, when using W5, whereas there was no reduction when using W4.

Ünlünkara et al. (2010) classified eggplant as moderately sensitive to salinity; however, in the present study it was possible to observe that the application of W2 $\left(2.5 \mathrm{dS} \mathrm{m}^{-1}\right)$ via $\mathrm{CD}$ led to a mean of $544.43 \mathrm{~g} \mathrm{plant}^{-1}$ and this value was the lowest one for the MY, close to that found by Lima et al. (2015), who applied saline water with $6.0 \mathrm{dS} \mathrm{m}^{-1}$ and obtained 532.92 g plant $^{-1}$, so they classified eggplant crop as sensitive to salinity.

The application of $\mathrm{W} 4$ via $\mathrm{PD}$ led to no difference in the mean values of yield (1559.22 g plant $^{-1}$ ) between TY and MY, which is favorable. This value was very close to that obtained by Lima et al. (2015), who used irrigation water with salinity of $0.5 \mathrm{dS} \mathrm{m}^{-1}$ and obtained an average yield of $2087.58 \mathrm{~g} \mathrm{plant}^{-1}$. According to results, these authors affirmed that with each unit increase in salinity there was a reduction of $282.12 \mathrm{~g} \mathrm{plant}^{-1}$, which makes it possible to infer the value of $1523.34 \mathrm{~g} \mathrm{plant}^{-1}$, for the electrical conductivity of $2.5 \mathrm{dS} \mathrm{m}^{-1}$, which was used in the present study.

The highest yield, associated with wastewater, shows what was observed in the study conducted by Tripathi et al. (2016),

Table 2. Total yield and marketable yield of eggplant, as a function of the type of water and drip irrigation system

\begin{tabular}{|c|c|c|c|c|}
\hline \multirow{3}{*}{$\begin{array}{l}\text { Type } \\
\text { of water }\end{array}$} & \multicolumn{4}{|c|}{ Means } \\
\hline & \multicolumn{2}{|c|}{ Total yield (g plant ${ }^{-1}$ ) } & \multicolumn{2}{|c|}{ Marketable yield (g plant ${ }^{-1}$ ) } \\
\hline & PD & CD & PD & CD \\
\hline W1 & $1253.71 \mathrm{aAB}$ & $1587.62 \mathrm{aA}$ & $1145.73 \mathrm{aAB}$ & $1296.36 \mathrm{aA}$ \\
\hline W2 & $1333.41 \mathrm{aA}$ & $1070.93 \mathrm{aA}$ & $1285.31 \mathrm{aA}$ & $544.43 \mathrm{bB}$ \\
\hline W3 & $765.45 \mathrm{bB}$ & $1355.82 \mathrm{aA}$ & $721.19 \mathrm{aB}$ & $931.22 \mathrm{aAB}$ \\
\hline W4 & $1559.22 \mathrm{aA}$ & $1492.53 \mathrm{aA}$ & $1559.22 \mathrm{aA}$ & $967.49 \mathrm{bAB}$ \\
\hline W5 & $1397.53 \mathrm{aA}$ & $1335.67 \mathrm{aA}$ & $1055.07 \mathrm{aAB}$ & $1078.98 \mathrm{aAB}$ \\
\hline CV (\%) & \multicolumn{2}{|c|}{22.02} & \multicolumn{2}{|c|}{27.86} \\
\hline
\end{tabular}

Means followed by the same lowercase letter in the row and uppercase letter in the column do not differ by Tukey test at $\mathrm{p} \leq 0.05$; CD - Continuous drip; PD - Pulse drip; W1 Supply water; W2 - Saline water $(\mathrm{NaCl})$; W3 - Saline water $\left(\mathrm{CaCl}_{2}\right)$; W4 - Wastewater W5 - Mixture of saline water $(\mathrm{NaCl})$ and wastewater who state that the cultivation of eggplant using wastewater via drip irrigation promotes nutrient savings and higher crop yield, compared with water from the water table.

The highest means of WUETOT were obtained with the application of W4 via PD $\left(7.56 \mathrm{~kg} \mathrm{~m}^{-3}\right)$ and this type of water only differed from W3 $\left(5.00 \mathrm{~kg} \mathrm{~m}^{-3}\right)$, which also showed no statistical difference from the others. However, application of W4 via CD led to the lowest WUETOT $\left(4.78 \mathrm{~kg} \mathrm{~m}^{-3}\right)$ and this differed only from $\mathrm{W} 1\left(7.31 \mathrm{~kg} \mathrm{~m}^{-3}\right)$, which also did not differ from the others (Table 3). When applying W3, CD led to higher mean compared to $\mathrm{PD}$, equal to $39 \%$; the opposite occurred when W4 was applied, with PD leading to a $58.2 \%$ higher mean (Table 3 ).

Almasraf \& Salim (2018) obtained WUE of $3.71 \mathrm{~kg} \mathrm{~m}^{-3}$ when irrigating eggplant with a drip system; this result was lower than that obtained in the present study with irrigation via $P D$, which can be justified since the use of this technique allows a reduction in the amount of water applied, maintenance of soil moisture, increase in yield, among other factors (Eid et al., 2013).

For WUEMAR (Table 3), the highest mean was similar to that obtained for WUETOT, because there was no scrap. Therefore, this occurred when applying W4 via PD $\left(7.56 \mathrm{~kg} \mathrm{~m}^{-3}\right)$, but it differed only from W3, which also did not differ from the others. The lowest mean of WUEMAR was obtained via CD when irrigating with $\mathrm{W} 2\left(2.54 \mathrm{~kg} \mathrm{~m}^{-3}\right)$, which differed statistically only from W1 and W5. Among the types of drip system, PD obtained a higher result than CD when W2 and W4 were applied.

Nasiraei et al. (2018) obtained a mean WUE of $2.6 \mathrm{~kg} \mathrm{~m}^{-3}$ using $50 \%$ of the water required, when studying eggplant with production in two years in a row (2012 and 2013). This value is very close to the lowest mean of WUEMAR via CD $\left(2.54 \mathrm{~kg} \mathrm{~m}^{-3}\right)$, which in turn can be associated with the salinity promoted in the soil by irrigation with $\mathrm{W} 2$, since excess salts in the root zone can cause effects similar to those of drought (water deficit) on plants.

Based on the difference between the type of drip system with the use of wastewater (W4), it can be inferred that this occurs due to the split application of water by the PD, which promotes better absorption by roots due to the higher concentration of water in the root zone, as evidenced in previous studies (Eid et al., 2016).

Table 3. Water use efficiency for total production (WUETOT) and for marketable production (WUEMAR) of eggplant, as a function of the type of water and drip irrigation system

\begin{tabular}{|c|c|c|c|c|}
\hline \multirow{3}{*}{$\begin{array}{c}\text { Type } \\
\text { of water }\end{array}$} & \multicolumn{4}{|c|}{ Means } \\
\hline & \multicolumn{2}{|c|}{ WUETOT $\left(\mathrm{kg} \mathrm{m}^{3}\right)$} & \multicolumn{2}{|c|}{ WUEMAR $\left(\mathrm{kg} \mathrm{m}^{3}\right)$} \\
\hline & PD & CD & PD & CD \\
\hline W1 & $5.92 \mathrm{aAB}$ & $7.31 \mathrm{aA}$ & $5.41 \mathrm{aAB}$ & $5.97 \mathrm{aA}$ \\
\hline W2 & $6.38 \mathrm{aAB}$ & $5.00 \mathrm{aB}$ & $6.15 \mathrm{aAB}$ & $2.54 \mathrm{bC}$ \\
\hline W3 & $5.00 \mathrm{bB}$ & $6.95 \mathrm{aAB}$ & $4.72 \mathrm{aB}$ & $4.77 \mathrm{aABC}$ \\
\hline W4 & $7.56 \mathrm{aA}$ & $4.78 \mathrm{bB}$ & $7.56 \mathrm{aA}$ & $3.10 \mathrm{bBC}$ \\
\hline W5 & $7.09 \mathrm{aAB}$ & $6.65 \mathrm{aAB}$ & $5.48 \mathrm{aAB}$ & $5.26 \mathrm{aBC}$ \\
\hline CV (\%) & \multicolumn{2}{|c|}{20.68} & \multicolumn{2}{|c|}{27.05} \\
\hline
\end{tabular}

Means followed by the same lowercase letter in the row and uppercase letter in the column do not differ by Tukey test at $\mathrm{p} \leq 0.05$; CD - Continuous drip; PD - Pulse drip; W 1 Supply water; W2 - Saline water $(\mathrm{NaCl})$; W3 - Saline water $\left(\mathrm{CaCl}_{2}\right)$; W4 - Wastewater; W5 - Mixture of saline water $(\mathrm{NaCl})$ and wastewater 


\section{Conclusions}

1. Pulse irrigation did not favor the number of fruits when applying saline water with $\mathrm{CaCl}_{2}$.

2. Pulse irrigation promoted lower loss of eggplant fruits, with small reductions between total and marketable production. The loss was null when pulse irrigation was associated with wastewater.

3. Wastewater along with pulse irrigation can be used in eggplant cultivation to obtain higher marketable production and water use efficiency.

\section{ACKnowledgments}

The authors thank the support from Coordenação de Aperfeiçoamento de Pessoal de Nível Superior (CAPES) for granting the scholarship and financial assistance (PROAP) to the Programa de Pós-Graduação em Engenharia Agrícola (PPGEA/UFRB).

\section{Literature Cited}

Almasraf, S. A.; Salim, A. H. Improvement of the water use efficiency and yield of eggplant by using subsurface water retention technology. Journal of Engineering, v.24, p.152-160, 2018. https:// doi.org/10.31026/j.eng.2018.03.12

Almeida, W. F. de. Gotejamento por pulsos e cobertura do solo na produtividade da alface americana. Lavras: UFLA, 2016. 79p. Tese Doutorado

Antonini, A. C. C.; Robles, W. G. R.; Tessarioli Neto, J.; Kluge, R. A. Capacidade produtiva de cultivares de berinjela. Horticultura Brasileira, v.20, p.646-648, 2002. https://doi.org/10.1590/S010205362002000400027

Costa, L. R. da; Gurgel, M. T.; Alves, S. M. C.; Mota, A. F.; Azevedo, J. de; Almeida, J. P. N. de. Crescimento de mudas de cajueiro anão precoce irrigado com efluente doméstico tratado. Revista Brasileira de Ciências Agrárias, v.7, p.421-426, 2012. https://doi. org/10.5039/agraria.v7i3a1562

Cunha, A. H. N., Oliveira, T. D.; Ferreira, R. B.; Milhardes, A. L. M.; Silva, S. D. C. O reuso de água no Brasil: A importância da reutilização de água no país. Enciclopédia Biosfera, v.7, p.12251248, 2011.

Dias, N. da S.; Blanco, F. F. Souza, E. R. de; Ferreira, J. F. da S.; Sousa Neto, O. N. de; Queiroz, I. S. R. de. Efeitos dos sais na planta e tolerância das culturas à salinidade. In: Gheyi, H. R.; Dias, N. da; Lacerda, C. F. de. Gomes Filho, E. (ed.) Manejo da salinidade na agricultura: Estudos básicos e aplicados. Fortaleza: INCTSal, 2016. Cap.11, p.151-162.

Dourado Neto, D.; Nielsen D. R.; Hopmans, J. W.; Reichardt, K.; Bacchi, O. O. S. Software to model soil water retention curves (SWRC, version 2.00). Scientia Agricola, v.57, p.191-192. 2000. https://doi.org/10.1590/S0103-90162000000100031

Eid, A. R.; Bakry, B. A.; Taha, M. H. Effect of pulse drip irrigation and mulching systems on yield, quality traits and irrigation water use efficiency of soybean under sandy soil conditions. Agricultural Sciences, v. 4, p.249-261. 2013. https://doi.org/10.4236/as.2013.45036
Eid, A. R.; Bakry, B. A.; Taha, M. H. Performance of drip irrigated soybean under mulching: Egypt. In: Goyal, M. R.; Chavan, V. K.; Tripathi, V. K. (ed.) Innovations in micro irrigation technology. Bota Raton: CRC Press, 2016. Cap.7, p.249-272.

Ferreira, D. F. Sisvar: A guide for its bootstrap procedures in multiple comparisons. Ciência e Agrotecnologia, v.38, p.109-112, 2014. https://doi.org/10.1590/S1413-70542014000200001

Genuchten, M. T. van. A closed-form equation for predicting the conductivity of unsaturated soils. Soil Science Society of American Journal, v.44, p. 892-898, 1980. https://doi.org/10.2136/ sssaj1980.03615995004400050002x

Lima, L. A.; Oliveira, F. de A. de; Alves, R. de C.; Linhares, P. S. F.; Medeiros, A. M. A. de; Bezerra, F. M. S. Tolerância da berinjela à salinidade da água de irrigação. Revista Agro@mbiente On-line, v.9, p.27-34. 2015. https://doi.org/10.5327/Z19828470201500012202

Medeiros, A. de S.; Nobre, R. G.; Campos, A. C.; Queiroz, M. M. F. de; Magalhães, I. D.; Ferraz, R. L. de S. Características biométricas e acúmulo de fitomassa da berinjeleira sob irrigação com água residuária e doses de nitrogênio e fósforo. Revista Brasileira de Agricultura Irrigada, v.11, p.1975-1985, 2017. https://doi. org/10.7127/rbai.v11n700665

Medeiros, A. de S.; Nobre, R. G.; Ferreira, E. da S.; Araújo, W. L. de; Queiroz, M. M. F. de. Crescimento inicial da berinjeleira sob adubação nitrogenada e fosfatada e irrigada com água de reuso. Revista Verde de Agroecologia e Desenvolvimento Sustentável, v.10, p.34-40, 2015. https://doi.org/10.18378/rvads.v10i3.3656

Medeiros, A. de S.; Queiroz, M. M. F. de; Araújo Neto, R. A.; Costa, P. S.; Campos, A. C.; Feraz, R. L. S.; Magalhães, I. D.; Maia Júnior, S. O.; Melo, L. D. F.; Gonzaga, G. B. M. Yield of the okra submitted to nitrogen rates and wastewater in Northeast Brazilian semiarid region. Journal of Agricultural Science, v.10, p.409-416, 2018. https://doi.org/10.5539/jas.v10n4p409

Moura, D. C. M.; Carvalho, J. de A. Efeitos de diferentes lâminas e teores de sais na água de irrigação sobre o desenvolvimento e produção da berinjela. Irriga, v.19, p.35-45, 2014. https://doi. org/10.15809/irriga.2014v19n1p35

Nasiraei, J. R.; Ansari, H.; Esmaeili, K.; Alizadeh, A. Effect of irrigation timing on the eggplant performance under drip irrigation. Crop Research, v.53, p.81-87, 2018. https://doi.org/10.5958/24541761.2018.00013.X

Santos, J. M. A. P. dos; Oliveira, F. de A. de, Medeiros, J. F. de, Targino, A. J. de O.; Costa, L. P. da; Santos, S. T. dos. Saline stress and potassium/calcium ratio in fertigated eggplant. Revista Brasileira de Engenharia Agrícola e Ambiental, v.22, p.770-775, 2018. https://doi.org/10.1590/1807-1929/agriambi.v22n11p770-775

Trani, P. E. Calagem e adubação para hortaliças sob cultivo protegido. Campinas: Instituto Agronômico de Campinas, 2014. 25p.

Tripathi, V. K.; Rajput, T. B. S.; Patel, N.; Kumar, P. Effects on growth and yield of eggplant (Solanum melongema L.) under placement of drip laterals and using municipal wastewater. Irrigation and Drainage, v.65, p.480-490, 2016. https://doi.org/10.1002/ird.1971

Ünlünkara, A.; Kurunc, A.; Kemiz, D. G.; Yurtseven, E.; Suarez, D. L. Effects of salinity on eggplant (Solanum melongena L.) growth and evapotranspiration. Journal of Irrigation and Drainage, v.59, p.203-214, 2010. 